\title{
nature gives and nature takes: a qualitative comparison between canadian and ger- man children about their concepts of 'nature'1
}

\author{
parmis aslanimehr ${ }^{2}$ \\ university of british columbia, canada \\ eva marsal, gemany ${ }^{3}$ \\ university of education karlsruhe, \\ barbara weber ${ }^{4}$ \\ university of british columbia, canada \\ fabian knapp 5 \\ realschule rheinau in rheinau-freistett, germany
}

abstract

As concerns of the Earth heading towards environmental change is gaining more prominence, this article will introduce a pilot study intended to investigate the common ideas children have about nature and how such ideas emerge within a philosophical community of inquiry. We are particularly interested in a cultural comparison between German and Canadian children in order to see if cultural developments influence how children understand and feel about nature. This pilot study contributes towards a greater understanding of underlying cultural differences of perceptions of nature within children. The intent of this study was to investigate how from an early age, children form a relationship with nature, and the effect nature can have on children's relationships with themselves, others, and their environment. Furthermore, the process of philosophical inquiry may lend sensitivity to how children reflect and feel as they grow in today's culture focused on environmental sustainability and economic development. Although previous research has explored children's conceptualization of nature, a qualitative approach through the Philosophy for Children paradigm has not been implemented before this study. This study focuses on 16 Canadian children aged 9 to 13 years and 12 German children whose ages ranged from 7 to 15 years to illustrate how specific preconceived notions of nature can shape our individuality and connection to wider human and ecological relationships.

keywords: philosophy for children, philosophy of nature, environment, canadian-german comparison

\section{natureza dá e natureza leva: uma comparação qualitativa entre crianças canadenses e alemãs sobre seus conceitos de "natureza"}

resumo

Com as preocupações acerca da passagem da Terra por uma transição ambiental se tornando mais proeminentes, este artigo pretende introduzir um estudo piloto que busca investi-

\footnotetext{
1 This project was generously funded by the HSS Seed Fund (UBC).

2 E-mail: parmisa23@gmail.com

${ }^{3}$ E-mail: marsal@ph-karlsruhe.de

4 E-mail: barweber@mail.ubc.ca

${ }^{5}$ E-mail: fabian.knapp@t-online.de
} 
nature gives and nature takes: a qualitative comparison between canadian and german children about their concepts of 'nature'

gar as ideias comuns que as crianças têm a respeito da natureza, e o modo como tais ideias emergem no contexto de uma comunidade de investigação filosófica. Estamos particularmente interessados em uma comparação cultural entre crianças alemãs e canadenses, de modo a notar se as diferenças culturais exercem influência sobre o modo como as crianças entendem e se sentem a respeito da natureza. Este estudo piloto contribui a um melhor entendimento das diferenças culturais que subjazem a percepção da natureza pelas crianças. O propósito deste estudo é de investigar como, desde uma idade tenra, as crianças formam uma relação com a natureza, assim como o efeito que a natureza pode ter nas relações das crianças consigo mesmas, com os outros, e com seu ambiente. Além disso, o processo de investigação filosófica pode fornecer sensibilização à como as crianças refletem e sentem-se, conforme crescem dentro da atual cultura focada na sustentabilidade ambiental e desenvolvimento econômico. Apesar do fato de pesquisas anteriores terem explorado a conceptualização infantil da natureza, uma abordagem qualitativa através do paradigma da Filosofia para Crianças ainda não foi implementado antes do presente estudo. Este estudo foca em 16 crianças canadenses com idades entre 9 e 13 anos e 12 crianças alemãs com idades entre 7 e 15 anos, para ilustrar como específicas noções pré-concebidas de natureza podem moldar nossa individualidade e nossa conexão com relacionamentos humanos e ecológicos mais amplos.

palavras-chave: filosofia para crianças; filosofia da natureza; meio ambiente; comparação alemã-canadense.

\section{la naturaleza da y la naturaleza toma: una comparación cualitativa entre niños canadien- ses y alemanes acerca del concepto de naturaleza}

resumen

Con las preocupaciones en torno al paisaje de la tierra por un cambio climático se hacen más prominente, este artículo pretende introducir un estudio piloto que busca investigar las ideas en común que los niños y niñas tienen en relación a la naturaleza y el modo como esas ideas emergen en el contexto de una comunidad de investigación filosófica. Estamos particularmente interesados en una comparación cultural entre niños y niñas alemanas y canadienses. De manera que podamos notar si las diferencias culturales ejercen influencia en la forma en cómo los niños y niñas entienden y se siente respecto de la naturaleza. Este estudio piloto contribuye con un mejor entendimiento de las diferencias culturales que subyacen en la percepción de la naturaleza por los niños y niñas. El propósito del estudio es investigar cómo, desde una corta edad, los niños y niñas crean una relación con la naturaleza, así como el efecto que la naturaleza puede tener en las relaciones de los niños y niñas consigo mismo, con otros y otras, y con su entorno. Además de eso, el proceso de investigación filosófica puede ofrecer sensibilización a la forma en cómo los niños y niños reflexionan y se sienten, conforme van creciendo dentro de la actual cultura enfocada en la sustentabilidad ambiental y desarrollo económico. A pesar de que que investigaciones anteriores han explorado la conceptualización infantil de la naturaleza, hasta ahora, un abordaje cualitativo a través del paradigma de la Filosofia para Ninos y Ninas, aún no fue implementado. Este estudio se enfoca en 16 niños y niñas canadienses, entre 9 y 13 años de edad y 12 niños y niñas alemanas, entre 7 y 15 años de edad, para ilustrar cómo específicas no- 
ciones preconcebidas de naturaleza pueden modelar nuestra individualidad y nuestra conexión con relaciones humanas y ecológicas más amplias.

palabras claves: filosofía para niños y niñas; filosofía de la naturaleza; medio ambiente; cooperación alemana- canadiense. 
nature gives and nature takes: a qualitative comparison between canadian and german children about their concepts of 'nature'

nature gives and nature takes: a qualitative comparison between canadian and german children about their concepts of 'nature'

\section{1. introduction and literature review}

"Within the entire philosophy of nature there is no word that is more ambiguous, more equivocal, than the very word that gave her [the discipline] its name, i.e. the word povols, that the Romans translate with the term 'natura'" (Christoph Sturmius, quoted in Spaemann, 1973, p. 956).

With this observation, the philosopher Christoph Sturmius (1635-1703) refers to the ambiguity that can already be found in its etymological roots: i.e. the Latin word "natura" (from nasci = being born), which has been equated with the Ancient Greek word "physis" ( $\varphi$ violৎ) (see SCHÄFER 1998, p. 728); both terms "see the process of becoming, growing, blossoming and sprouting as well as the properties and the essence of a something" (SCHIEMANN, 1996, p. 12).

The contemporary German natural philosopher Ottfried Hoeffe picks up these rather ambiguous properties of nature when he distinguishes a 'material understanding' from a 'formal understanding': "[nature is] the entirety of all observable, nonman-made things; things that are grown (organic or non-organic); plant-based or animals (i.e. material based concept of nature). In addition, it [nature] is the epitome of all properties of a thing that we can experience as regular or that follow a particular pattern (i.e. formal concept of nature)" (HÖFFE, 2008, p. 223).

Thus, the 'material understanding' entails all the processes, things and beings of nature, which have evolved without the assistance of humans, e.g. storms, earthquakes, water, earth, rocks, plants, animals, etc. Throughout the history of philosophy, this material understanding of nature has often been described with the help of antinomes: for examples, the nature as the "antinome to humans and human actions (Aristotle), to mind (Hegel), to freedom (Kant), to history (Droysen), to culture and society 
(Hobbes, Locke)" (HÖFFE, 2008, p. 223), as well as to technology. This can be further defined through internal differentiations such as "animate and inanimate nature, internal and external nature, divine, human, animal, floral and mineral nature [...]" and so on (SCHÄFER, 1998, p. 728).

Furthermore, the literary critic, Raymond Williams (1984, p. 198), describes nature as "the most complex word in the language" not only because of its ambiguity, but also because of its cultural and historical contingency. Throughout history nature has been perceived to be a provider of life (e.g. in the notion of 'mother earth'); as a threat or destructive force (e.g. natural catastrophes or the 'dark forest' deemed to be dangerous); as disenchanted and controllable by natural sciences and technology (e.g. industrialization); and as an extremely vulnerable ecosystem damaged by humans (e.g. the discovery of the ozone hole and its consequences). Specifically, the drastic environmental changes that were first brought on by industrialization scattered the unconditioned belief in a merely scientific concept of nature, whereby nature became a "predictable, causal and mechanical context that [could] be grasped and is there to be manipulated and mastered by the improvement of technology"6 (PÄTZOLD 2003, p. 1). ${ }^{7}$ The ecological crisis in the 1980s dramatized this change of perspective and revitalized a more spiritual and romantic understanding of nature. Schäfer (1998, p. 732) described such a viewpoint of 'nature' as "[...] what we once described as inexhaustible, indestructible, revolving, self-perpetuating and healing, mother earth, we suddenly experience as vulnerable, destructible, precious good, that humans have to protect and preserve" ${ }^{8}$ Furthermore, contemporary philosophers like Hans Jonas, Peter Singer or John Passmore advocate for more responsibility and protection of nature. They argue

${ }^{6}$ Original in German: „berechenbaren, kausalmechanischen Gesetzeszusammenhang zu begreifen und dadurch für die technische Manipulation zu erschließen" (translation by B. Weber).

${ }^{7}$ Of course, the seeds of this view of nature as a machine to be mastered is already at work in earlier thinkers in philosophy and science, for example, Francis Bacon, Descartes and others.

8 Original in German: Die Natur, „, die wir einst in Begriffen wie unerschöpflich, unzerstörbar, sich selbst erneuernd und heilend oder auch als große Nährmutter umschrieben haben, wird nun als verletzlich und zerstörbar erfahren, als ein kostbares Gut, das die Menschen hüten und bewahren sollen" (translation by B.Weber). 
nature gives and nature takes: a qualitative comparison between canadian and german children about their concepts of 'nature'

that if we recognize nature as a 'juristic person' then plants, animals and landscapes would have a right to be protected. Adolf Meyer-Abich (1989, pp. 254-276; 1997) calls this viewpoint 'a legal community with nature'.

To this date, a number of studies can be found that investigate children's ideas about nature. One example is a study by Collado, Íñiguez-Rueda and Corraliza (2016). They investigated the experiences that children have with nature (urban, rural mountain range, and rural agricultural) to illuminate the role of personal and situational characteristics, which in turn shape children's constructions of the natural world. Another study (WHITE, 2015) researched children's conceptualization of nature through the use of digital cameras to allow them to theorize about complex concepts during nature-based learning experiences. Both studies were done with children who received home education. In addition, one study measured how children's conceptualization of nature affected their biophilic attitudes towards wildlife only (ZHANG; GOODALE; CHEN, 2014). Other studies discussed children's perceptions and ideas about nature. However in such studies, the definition of nature remained more limited to animals or play spaces (GURHOLT; SANDERUD, 2016; FRANCIS; PAIGE; LLOYD, 2013). Yet, a cross-cultural study using philosophical inquiry with children as a research method in order to openly engage with children's concepts about nature has never been conducted to our knowledge.

\section{2. purposes and research design}

The pilot study, while aware of the complex and changing meanings of nature, aimed to better understand how young children think and feel about nature, as well as how they see themselves in relationship to nature. This is important because the future generation is to experience the greatest impact of the surfacing challenges to our planet. Thus, our intent was to give children the space to develop and express their thinking about nature in a broad and open way as well as to understand if children's concepts about nature differ in other parts of the world. Some of the topics we investigat- 
ed with children were, how nature can be threatening, such as the case of natural catastrophes or unpredictable weather conditions; have economic value, in resources such as wood, oil and water; is a place for recreation, in the case of engaging in activities such as swimming or hiking etc.; or is embedded in the roots of their identity or at the foundation of life in a spiritual and/or scientific sense. ${ }^{9}$ The explorations of such themes were made possible through engaging children in a semi-guided, philosophical discussion about nature. The American Pragmatist, John Dewey, who emphasized the social aspect of obtaining knowledge, proposed communal inquiry as a collaborative practice. For Dewey, knowledge was embedded within a social context where the members of the community become reflective and critical in their quest for intersubjective agreement. Only through this kind of communication will we form an actual community across differences. Dewey (1927, p. 142) wrote: “Till the Great Society is converted into a Great Community, the public will remain in eclipse. Communication can alone create a great community. Our Babel is not one of tongues but of the signs and symbols without which shared experience is impossible"

Moreover, and quite in contrast to Jean-Jacque Rousseau (1762), Dewey believed that we are not aware of our own thinking and attitudes until we engage in an open and critical dialogue (DEWEY, 1927). Thus, by engaging children in a dialogue, they might discover, become attentive of or change the way they think and feel about nature. Consequently, the authors regard the thinking and feeling of children as continuously evolving rather then being 'static'. In that sense, we are not 'measuring' their ideas, but rather 'listening into' their progression and unfolding of ideas.

We chose to design this study in the form of a philosophical Community of Inquiry in order to provide children the opportunity to explore their own ideas in relation to their peers in a constructive, and non-competitive way. Further in reference to Dewey, we intended that by doing so, children may enhance their reasoning, mutual

\footnotetext{
${ }^{9}$ These are some of the topics that came up in the discussion with the children.
} 
nature gives and nature takes: a qualitative comparison between canadian and german children about their concepts of 'nature'

understanding, as well as their self-awareness (WEBER, 2015). In addition, the Community of Inquiry and its incorporation of democratic dialogue allows children to break with existing schemes of thinking, increase their sensibility for different criteria of their values as well as sharpen their awareness of what constitutes their relationship towards nature and the environment. It is through this refined awareness that not only reveals how one appears to others but how one becomes sensitive to what is creating us from the inside.

\section{3. method}

\section{1. participants}

This study took place in three classrooms: two in Vancouver, British Columbia and one in Karlsruhe, Germany. As nature is a loaded term, through applying a comparative methodology between two cities similar in size yet different in culture yields insight on the distinctive characteristics of conceptualization of nature by children. This study contributes to an awareness of how conceptions of nature take shape in two countries that are classified as Western but differ in culture, history and educational policies. We were particularly interested if any differences that occur in the children's views of values and arguments about nature, in order to justify funding for a future cross-cultural research project. As the science of human development seeks to understand how children may differ as they develop, such cross-cultural qualitative research is integral towards understanding the meanings, interpretation and subjective experiences that children may have, as they are faced with the same changing phenomena in different parts of this planet. Such inquiry allows researchers and educators to hear the voices of children, in their own words of their feelings and experiences. The participants were 16 Canadian children whose ages ranged from 9 to 13 years, 11 boys and 5 girls and 12 German children whose ages ranged from 7 to 15 years, 9 boys and 3 
girls. ${ }^{10}$ All of the participants were born and raised in the respective country/city/area where we were conducting the discussions.

The Vancouver schools were chosen based on their representativeness of the range of socioeconomic and racial/ethnic diversity of students in the school district. The German children philosophized in the context of an educational setting called 'Kinder-Universitaet Bretten' (English translation: Children's University), where children visit a university and engage with a professor of a specific discipline in order to learn about university learning and research.

We chose the age period between 9 to 15 years, as it is during this developmental period that children's personalities, behaviours, and competencies may flourish into forms that echo into adolescence and into adulthood (ECCLES; ROESER, 2009). The topic of 'nature' provides a place of sensory experiences. Children develop attitudes and beliefs about how much control humans may or may not have over nature, their helplessness along with how they can save it. For the German children we had a wider variety of ages, because we did not want to exclude the two younger ones who also wanted to participate.

All children were familiar with Philosophy for Children and had participated regularly in Communities of Inquiries. The facilitation was done by the two PIs of this project, i.e. Eva Marsal and Barbara Weber. In Vancouver, we arranged for two Philosophy for Children sessions of 60 minutes. In Germany, within the Kinder-Universitaet Bretten, there was only one 90-minute session, where the children had been doing Philosophy for Children for several years. ${ }^{11}$ The lessons were recorded and transcribed so that we were able to implement a content-analytical appraisal of the children's views and their arguments (MARSAL; DOBASHI, 2009).

\footnotetext{
${ }^{10}$ In the original proposal as well as the discussions with the children, we first had also included children as young as 5 years; however for the actual analysis we focused on older children.

11 A "University for Children" is an educational model in Germany, where the children come to the public university in order to learn about different disciplines from university professors. Within that framework the children have been working with Dr. Eva Marsal for several years.
} 
nature gives and nature takes: a qualitative comparison between canadian and german children about their concepts of 'nature'

For the Canadian portion of this research, ethics approval to conduct the research was obtained both from the university, and the school board of the participating school districts. Parental permission forms along with a letter from the school principal describing the research were given to students. Students were informed that their participation was voluntary, and that there would be no consequences if they chose not to participate. In Germany, however, no ethics board approval is required as long as parents are informed of the study informally. After excluding those whose parental consents were not available and children under the age of 7 years, the total of participants for qualitative analysis from Canada and Germany were 28 participants.

\section{2. research design: philosophy for children inquiry as a qualitative method}

Philosophy for Children (P4C) was originally developed by the American philosopher Matthew Lipman during the 1970s and has since spread across the world and morphed into various inquiry-based pedagogies. The 'philosophical Community of Inquiry' (CoI) usually lies at the heart of P4C. Here, children read philosophical novels or are exposed to other philosophically relevant stimuli and develop questions that are important to themselves. They then have the opportunity to think, reflect, and reason together while they are exposed to different perspectives of one another. This study used the P4C pedagogy as a research method in the interest of learning what children think and feel about nature. Here, $\mathrm{P} 4 \mathrm{C}$ is a qualitative method that combines inductive category coding with a simultaneous comparison of all units of meaning that is obtained. Each category is compared to all other units of meaning and subsequently categorized and coded with similar units of meaning. If no similar units of meaning emerge, a new category is formed. Here, philosophical inquiry creates room for continuous refinement as initial categories are changed or new categories are generated and new relationships can be discovered (MAYKUT; MOREHOUSE, 1994). In order to develop an inquiry in the classroom relating to nature, an emphasis was first placed on 
creating a sense of community. This is why we chose to do our study in already existing Communities of Inquiry in schools.

\subsection{1. procedure}

While we made an effort to be culture-sensitive, we tried to stick to a similar sequence for our facilitation. Each session began with the facilitator presenting a stimulus in the form of some pictures and would invite the children to a free association around the topic of nature. Following the stimulus, the actual discussion evolved around a discussion plan, which explored 'nature as threatening'; nature as 'life giving'; ethical questions around nature; as well as speculative questions. While we did try to tap into each of the themes that we developed from the history of ideas around nature, at the same time, we remained open to where the questions and ideas of the children led us. That is to say, the discussion plan gave us directions to visit different aspects around nature. However, whenever neither of the children picked up on that idea, we did not force that idea onto the children, but rather gave them the opportunity to offer their own ideas. In addition, we developed the discussion plan in a way that it would invite both the asking for examples (if the discussion remained too abstract) or the asking for definitions and reasons (if the discussion became too much of a 'story telling').12

Core elements of the Community of Inquiry were that the children built on each other's ideas and arguments, made continuous connections to the already-mentioned statements, gave reasons why they agreed or disagreed with others, and followed the argument to where it led them (KENNEDY, 2004). In our CoI we usually insist that children devote a longer time to one question or topic. In our case, however, we had

${ }^{12}$ For a further analysis of a CoI regarding different qualitative stages: see Weber 2013. 
nature gives and nature takes: a qualitative comparison between canadian and german children about their concepts of 'nature'

many different topics to touch upon and thus naturally we had not as much time to linger with some of the ideas and/or arguments. ${ }^{13}$

In addition to the dialogue, we invited the children to draw a picture of the most important aspect of what they had heard, thought or talked about in the CoI. Drawings have a very different characteristic than an idea that is verbally expressed. For example, a picture is still, yet embraces many elements; though the perspective that the child chooses is deliberate and unique. What has been included? What remains left out? In addition, the children drew the paintings reflectively by themselves, rather than in a group setting. Lastly the image represented what seemed the most important element, idea or thought for the children after engaging in a dialogue around nature. In that sense, the painting replaced the silent reflection and journal writing, which we usually have at the end of a CoI. Graduate research assistants were responsible for recording and transcribing each session as well as scanning all the drawings.

For the analysis, we had developed categories deductively through philosophical theories as well as inductively through the statements of the children, so that the statements of the children could be compared with one another. Thus, we ordered and numbered all statements (No. 1, 2, 3, etc.) as well as labeled them according to their nationality, gender and age: e.g. Canadian girl, 10 years is labeled as 'CG, 10 years'. All statements are subdivided into several single arguments, because often one statement entails many different arguments. With the development of the categories we followed the content-analytical research method by Philipp Mayring (2007). We did not conduct a test for significance, because - and as usual with qualitative research - the sample size is too small to be of representative value. We only quantitatively evaluated the qualitatively gained results through our content analysis of comparing the percentages of remarks from the dialogues. Although this pilot study is not of quantitative significance, it is of heuristic value: Through participating in a Community of Inquiry, the

${ }^{13}$ This is an aspect that we would like to change for the actual research project, i.e. that we can spend more time on each aspect of the dialogue. 
children explore and reflect on ideas in a collaborative, non-competitive fashion and develop and verify central arguments around the topic 'nature gives and nature takes'.

The deductively-inductively results of the philosophical system enveloped the following categories: a. Definitions, b. Emotional Qualities, c. Values and Significance and d. Fascinations. The deductive derivation led to the philosophically based input and questions yielded from the CoI, while the children's statements inductively defined the content of the categories. If the children's statements had opened up another category, we would have expanded our own system of deductively-gained categories. However, this was not the case. Two independent research fellows (evaluators) assigned all children's statements to the various categories. In order to comprehend the categories, we trained the evaluators (research fellows) as well as gave them some exemplary sentences. The interpretation follows a hermeneutic method. The examples of the German children in this article were translated to English. In the following sections, we are exemplifying each category by statements from both the German and Canadian children. They will be further differentiated and exemplified through central test sequences from the CoI.

\subsection{2. definition}

2 CB Liam (13):

"Nature, is like, a whole bunch of planets in the universe. Without the planets there would be no universe, so without nature there would be no earth."

99 GG Luisa (9):

"So, I think that we humans also belong to nature, because nature is everything that humans have not made, so everything that the human cannot make. Humans cannot make everything themselves."

The category of 'definitions' embraces phenomena of nature as well as the procedural character of nature. The children's definitions go beyond planet earth: they entail the entire universe. Human beings are a part of nature as well. These examples 
nature gives and nature takes: a qualitative comparison between canadian and german children about their concepts of 'nature'

will show how differentiated, complex and comprehensive children's understandings of nature are as well as signifying possible cultural differences.

\subsection{3. emotional qualities}

55 CB Rick (11):

"Most of the time peace and sometimes like shock."

235 GG Laura (9):

"I admire nature [...] how much food it produces for humans and for others."

The category 'emotional qualities' comprises all statements that entail an emotional attitude towards nature. Nature is seen as a safe haven where one can relax and recover from everyday life. Here, emotions like gratitude and admiration are being expressed. Whereas in confrontation with nature's destructive forces, emotions like fear or mental disturbance may arise as well.

\subsection{4. values and significance}

Positive Values:

212 GB Johannes (13):

"She gives us resources like minerals, e.g. iron, oil, things that we need. Everything that drives so well needs energy, e.g. from oil."

35 CG Mona (12):

"[Nature] gives to us, I think, so we have to give back. So say, we took down a tree, we have to plant new ones so that they'll come back. And it's kind of like a cycle."

Negative Values:

602 GB Michael (10):

"This photo shows how brutal a tempest or an earthquake can be, that tears open the ground. Nothing is like before. Here nature has an intimidating effect. Nature is turning against the human." 
25 CB Brian (12):

"I believe nature can be cruel, it's mad at us. But also nature includes us. And we are cruel to ourselves. Just because we might look different, just because we might have accents, just because we're different. Some people can't deal with that, so they have to make themselves noticed, and same with animals, same with nature. It's as simple as that."

This category, 'values and significance' features all statements where children either ascribe a moral value to nature (physiocentric thinking) or they ascribe values that are useful for themselves (anthropocentric thinking). In addition, this category embraces all statements regarding the protection of nature along with what significance nature holds for children.

\subsection{5. fascination}

05 CG Alexa (12):

"...you can just hear natural noises and hear the sounds of earth, and what was here before all of the cities, and all this construction happening, you can see and hear what was here before we were here."

408 GG John (15):

"Well, I do think that one can be fascinated by thunderstorms. I have been fascinated by thunderstorms. Remember, the example that I talked about before? It is just such a big force of nature; a force that humans could not make; and that is fascinating for me."

The category 'fascination' talks about which aspects children find fascinating about nature as well as the reasons why they find them fascinating.

\section{4. results and discussion}

Similar to how the philosophers reflected on the concept of nature, children also engaged with the complexity and openness of the concept of nature within the community of inquiry. Both, the German and Canadian children not only include the phenomena of nature, but also its procedural character. This is shown in their answers to the question, "What do you associate with the term 'nature'?" And particularly be- 
nature gives and nature takes: a qualitative comparison between canadian and german children about their concepts of 'nature'

cause the term nature can be understood in many ways, it was important to start with a clarification regarding the children's various ideas and understandings.

\section{1 quantitative representation of data}

In the following paragraphs we will first give a quantitative representation of the qualitative data. Taking into account the scope of this paper, we will only focus on the category 'definitions of nature' for our in-detail analysis and set aside the other three categories for now. ${ }^{14}$ Here we will first interpret the German children's discussions and then compare those with the Canadian children.

\subsection{1. german sample}

Raw Data regarding the statements about "Nature" of the German Children

$$
\text { Sum }[\mathrm{Z}\} \mathrm{N}=510 \text { (N=Arguments) }
$$

\begin{tabular}{|l|c|c|c|c|c|c|c|}
\hline & Definition & \multicolumn{2}{|c|}{ Emotional Qualities } & \multicolumn{2}{|c|}{ Values } & Fascination & Sum \\
\hline Frequency & 31 & \multicolumn{2}{|c|}{246} & \multicolumn{2}{|c|}{101} & 132 & 510 \\
\hline & & Positive & Negative & Positive & Negative & & \\
\hline & & 138 & 108 & 75 & 26 & & \\
\hline
\end{tabular}

Figure 3. Raw Data of German Children's statements about nature.

${ }^{14}$ For this paper we focus on an in-depth analysis of the category 'definition' only, since we will not have the space to discuss all four categories in-depth. However, we are working on analyzing all of the data and will publish the results in the form of a book. 


\subsection{2. canadian sample}

Raw Data regarding the statements about "Nature" of the Canadian Children Sum $[Z] N=285$ ( $N$ = Arguments)

\begin{tabular}{|l|c|c|c|c|c|c|c|}
\hline & Definition & \multicolumn{2}{|c|}{ Emotional Qualities } & \multicolumn{2}{|c|}{ Values } & Fascination & Sum \\
\hline Frequency & 113 & \multicolumn{2}{|c|}{20} & \multicolumn{2}{|c|}{112} & 40 & 285 \\
\hline & & Positive & Negative & Positive & Negative & & \\
\hline & & 14 & 6 & 88 & 24 & & \\
\hline
\end{tabular}

Figure 4. Raw data of Canadian children's statements about nature.

\subsubsection{German and Canadian Sample together}

Percentages regarding the types of statements from both the German and Canadian Children

Sum $[Z] N=795$ ( $N$ = Arguments)

\begin{tabular}{|c|c|c|c|c|c|c|c|}
\hline & $\begin{array}{c}\text { Defini- } \\
\text { tion }\end{array}$ & \multicolumn{2}{|c|}{ Emotional Qualities } & \multicolumn{2}{|c|}{ Values } & $\begin{array}{l}\text { Fascina- } \\
\text { tion }\end{array}$ & Total \\
\hline $\begin{array}{l}\text { German } \\
\text { Children }\end{array}$ & $6 \%$ & \multicolumn{2}{|c|}{$48 \%$} & \multicolumn{2}{|c|}{$20 \%$} & $26 \%$ & $100 \%$ \\
\hline \multirow{2}{*}{$\begin{array}{l}\text { Canadian } \\
\text { Children }\end{array}$} & $40 \%$ & \multicolumn{2}{|c|}{$7 \%$} & \multicolumn{2}{|c|}{$39 \%$} & $14 \%$ & $100 \%$ \\
\hline & & Positive & Negative & Positive & Negative & & \\
\hline $\begin{array}{l}\text { German } \\
\text { Children }\end{array}$ & $6 \%$ & $27 \%$ & $21 \%$ & $15 \%$ & $5 \%$ & $26 \%$ & $100 \%$ \\
\hline $\begin{array}{l}\text { Canadian } \\
\text { Children }\end{array}$ & $40 \%$ & $5 \%$ & $2 \%$ & $31 \%$ & $8 \%$ & $14 \%$ & $100 \%$ \\
\hline
\end{tabular}

Figure 5. Percentages regarding the type of statements from both German and Canadian children. 
nature gives and nature takes: a qualitative comparison between canadian and german children about their concepts of 'nature'

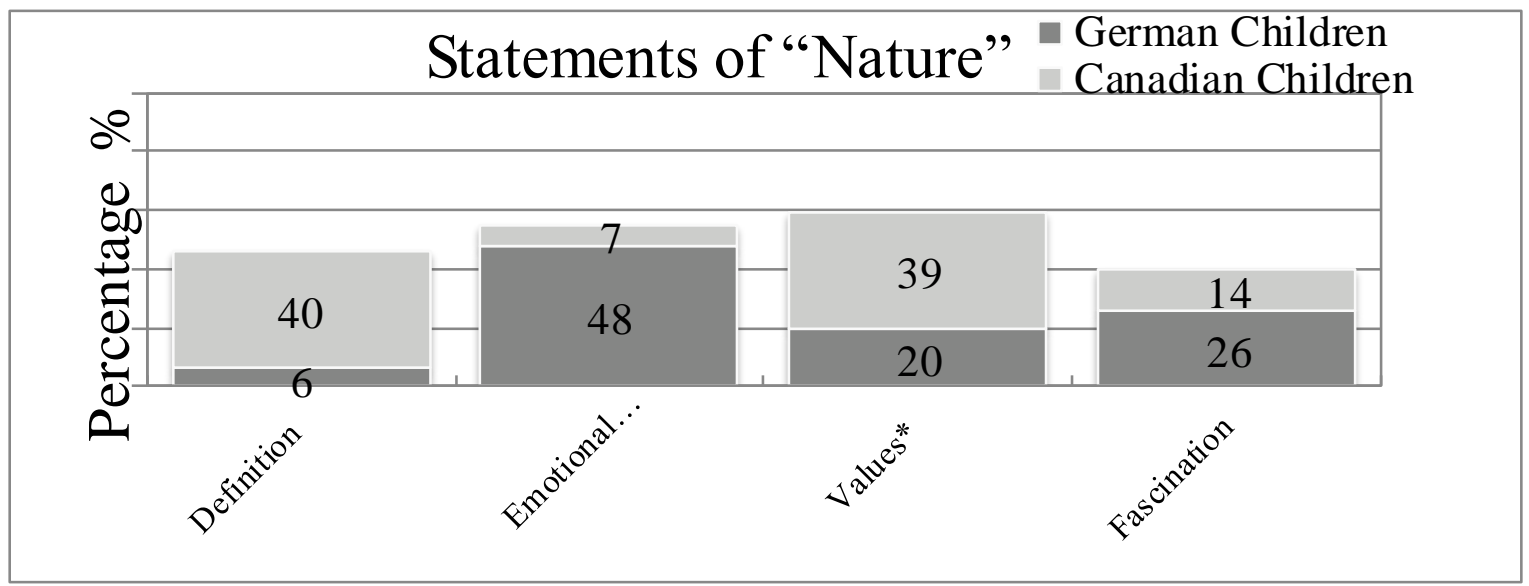

Figure 6. Bar graph depicting the percentages of the types of statements from both German and Canadian children. *The following graphs will further illustrate the cultural difference in attributing positive and negative qualities surrounding 'emotional qualities' and 'values' in nature

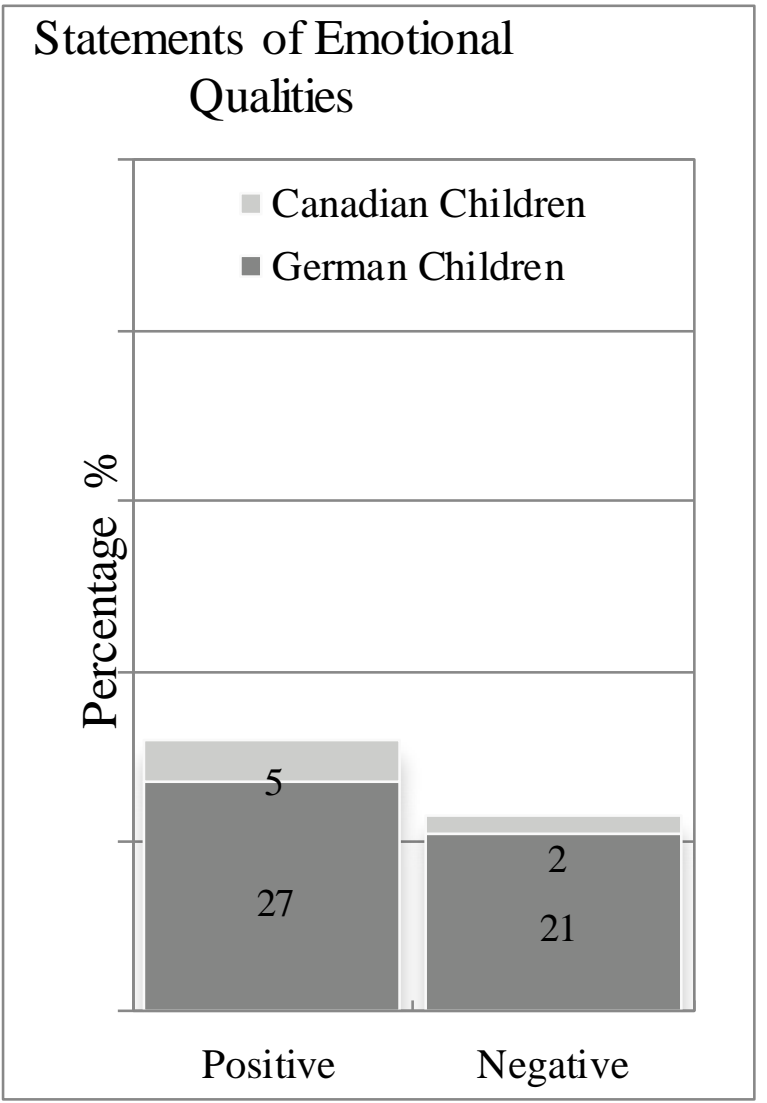

Figure 7. Bar graph depicting the percentages of positive and negative emotional qualities given to nature by German and Canadian children.

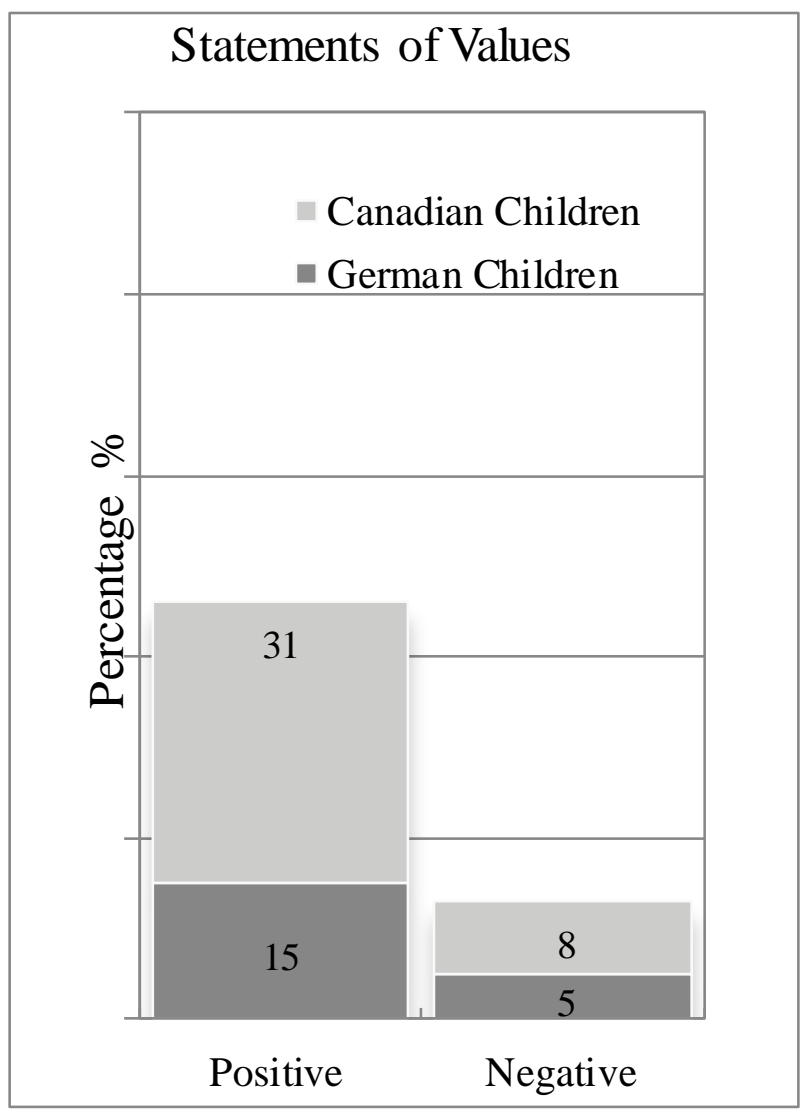

Figure 8. Bar graph illustrating the percentages of positive and negative values within nature given by German and Canadian children 


\section{2. definitions of the german children}

After exchanging some first ideas about the images of nature as life-giving and nature as destructive, the children discussed what they associated with the term "nature':

Sequence of the dialogue among the German children:

88 GG Laura (9):

"Trees, plants, water."

89 GB Johannes (13):

90 GB Kurt (7):

"Green stuff. Well, everything that is good from nature, green stuff, roots, blooming stuff, that starts small and then grows over years; sometimes that goes quickly; then there are not such good things, like Tsunamis, the strong storms, heavy rain, because this also destroys the ground."

"And there are also many animals; there are also rivers and streams."

93 GB John (15):

"For me everything that is natural belongs to nature; that means literally from the natural catastrophes to nature as a life giving source."

94 GG Laura (9):

"We, also we humans belong to nature."

98 GB Heather (8):

"For me it is the weather. Without different weathers it would be bad, because not so many plants would grow."

99 GG Luisa (9):

"So, I think that we humans also belong to nature, because nature is everything that humans have not made, everything that the human cannot make. Humans cannot make everything themselves."

This dialogue first focuses on concrete phenomena such as, 'trees, plants, water, green stuff' (8 GG, Laura), yet also 'animals, rivers, streams' and 'humans' (90, GB, Kurt, Age 7). It is then followed by statements of development like 'it starts small and then grows big' or 'the strong storms, heavy rain, [...] destroys the ground' (89, GB, 
nature gives and nature takes: a qualitative comparison between canadian and german children about their concepts of 'nature'

Johannes, Age 13). This means that the children proceed to more abstract concepts like the weather general or everything natural.

This is then being summarized by nine-year old Luisa in an anthropocentric manner: "nature, $[\ldots]$ is everything that humans have not made, so everything that the human cannot make." She is referring with that to technology, i.e. an aspect that has already been discussed as the 'opposite of nature' within the history of philosophy. For example, by Thomas Aquinas who was the first to introduce the difference between natura naturans and natura naturata (Schiemann, 1996). With this distinction he referred to the difference between the 'creating of nature', i.e. trees, flowers, animals, etc. and the 'created nature', i.e. artifacts. However, artifacts often do imitate nature something that already Aristotle pointed to in Physics Book II (Aristotle \& Charlton, 1992). This is also what the child John is pointing out when he says: "For example cockroaches... One has tried to imitate them." This is why in the earlier development of the argument within the $\mathrm{CoI}$ the children come to doubt the strict distinction between nature and technology. John argues: "Such a crass opposite is really rare ... I think a lot of what is not really 'natural' is in between, for example furniture that is made of wood. It is no longer just nature, but is still made of natural products" (97, GB, John, Age 15).

For the children, humans can intervene into the world of nature due to their intelligence, i.e. humans can create another world by making artifacts (e.g. technology or art). At the same time they can destroy nature. Thus, humans have an ambivalent role with regard to nature.

103 GB Johannes (13):

"We are flattening nature by cutting down all the forest or killing all the whales. We are also extinguishing other species."

Apart from Luisa, the German children are not justifying why or how the human belongs to nature. Luisa though, does not refer like the Canadian children do later, to the origins of humans or the body of humans. Her argument is that the human 
cannot 'make' him or herself. In that regard, Luisa's argument resembles the one of Hoeffe (2008, p. 223), for whom nature is "...the entirety of all observable, non-man-made things; things that are grown (organic or non-organic); plant-based or animals (i.e. material based concept of nature). We also see this definition in the painting of Alicia:

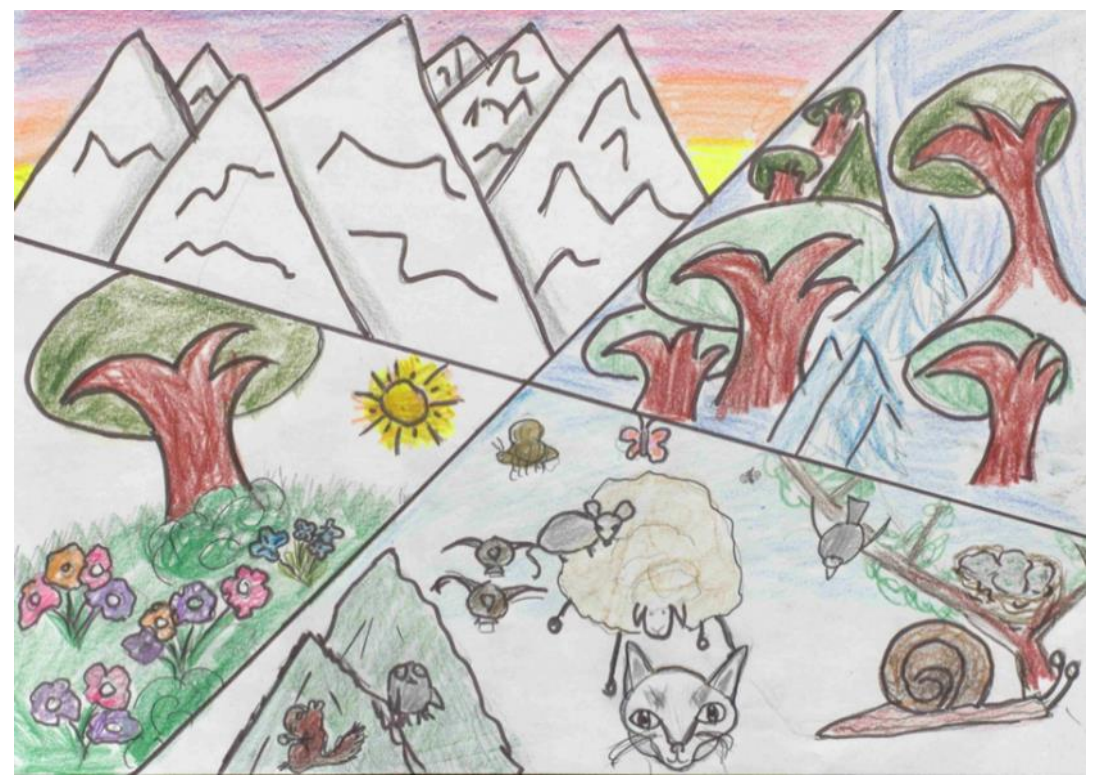

Figure 9. Definition of Nature. This figure is an illustration of how a 12 year-old German girl, Alicia, defined nature.

The mountains in the upper part of the painting show the inorganic part of nature. While the side parts with the plants and lower part with the animals represent the growing and organic nature. In summary, the German children arrived at a definition of nature that very much resembled the one of Aristotle, who sees nature as what is by and in of itself (HÖFFE, 2008). 
nature gives and nature takes: a qualitative comparison between canadian and german children about their concepts of 'nature'

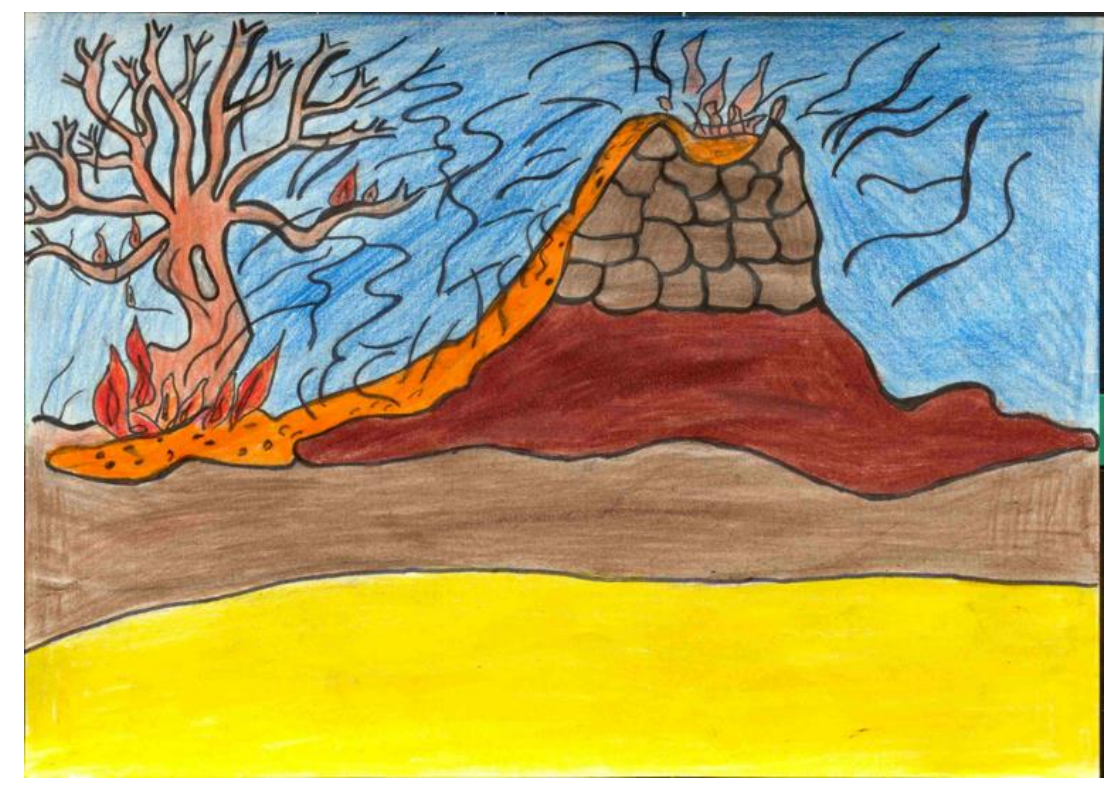

Figure 10. Definition of Nature. Eruption of a volcano illustrated by a German boy, Kevin, Age 11.

The fifteen-year-old John argues: “In nature everything hangs together. Like for example the forest fire and the hurricanes. When an entire forest burns down then not all life is dead; rather there is also the chance for new life to emerge. All the little trees that did not have a chance before to grow, they now have light and a completely new forest can develop. Of course, that takes a long time" (563, GB, John, Age 15).

The younger children, for example David and Kurt, are not seeing nature from a scientific standpoint, but rather take on an evaluative perspective. They ascribe moral values to nature like 'beautiful' in a sense of 'good' or also values like 'evil' or 'cruel'. However, Kurt is using the opposites of 'beautiful and evil' not only in an ethical sense, but also in an aesthetic sense when he says: "The beautiful side of nature is simply beautiful."

261 GB David (8):

"I see nature like if we were to cut the globe in half: one side is totally cruel and the other side is very good; this is how I see nature." 
596 GB Kurt (7):

"Nature is beautiful and evil, because of all the terrible things nature does; but then it is also amazing; all the things nature can do; the beautiful side of nature is simply beautiful."

The children's arguments are based on their observations of nature as continuously changing and never static. Their justifications resemble the Aristotelian principle of calmness This is why nature is able to accomplish all forms of change, renewal and reproduction on its own and thus creates and functions without any 'outside' influence. The children Heather and Johannes refer to this circle of life when the say:

61 GB Heather (8):

"Because we breath oxygen and then breathe out carbon dioxide and this is what the leaves breathe in and then breathe out oxygen. Thus, this is a cycle."

209 GB Heather (8):

"When birds eat seeds then they poop those out again, e.g. when they fly in the air. From those seeds trees grow and those produce air and seeds again."

202 GB Johannes (13):

"We are co-depend like in a spiral; though it is as if the cycle is never closing, never complete."

Therefore, the definitions of the German children are:

- Nature is everything that the humans have not made (dichotomy of culture and nature, i.e. materialistic concept of nature)

- Nature is used for the production of artifacts (integration of materials of nature and culture)

- Nature is development e.g. growing and vanishing (procedural dynamic)

- Nature is renewing itself, even after natural disaster (phenix argument)

- Nature is the cycle of life (dependence argument)

- Nature is evil (moral dimension)

- The human is part of nature because of the first definition 
nature gives and nature takes: a qualitative comparison between canadian and german children about their concepts of 'nature'

In the definitions of the German children we find the procedural characteristic of nature that is also pertinent in the Greek word púoı (Physis). ${ }^{15}$ The children also come back to a scientific concept of nature.

\section{3. definitions of the canadian children}

In summary, and while the Canadian children bring forth similar arguments as the German children, they introduce some additional aspects.

Sequence of the dialogue among the canadian children:

\section{a. the younger group of children}

19 CB Darren (9):

"I look at nature, like nature is something that gives us food and like actually is good... and like you can make stuff out of nature and that makes people happy kind of, so nature is good to us."

36 CG Emma (9):

"Hmm, well, when I think of nature I think of animals and the plants all living together. And since we are animals we should do the samething and not hurt other animals"

37 CG Mila (9):

"I think nature has a cruel part, well not that it is cruel to us but like natural disasters, the ones we were just looking at, the one where the water is coming, splashing cars down, like thunder storms."

15 "Physis" is both "the process of becoming growing, blossoming, opening as well as the essence of something" (Schiemann 1996, p. 12, translated by B.W.). 


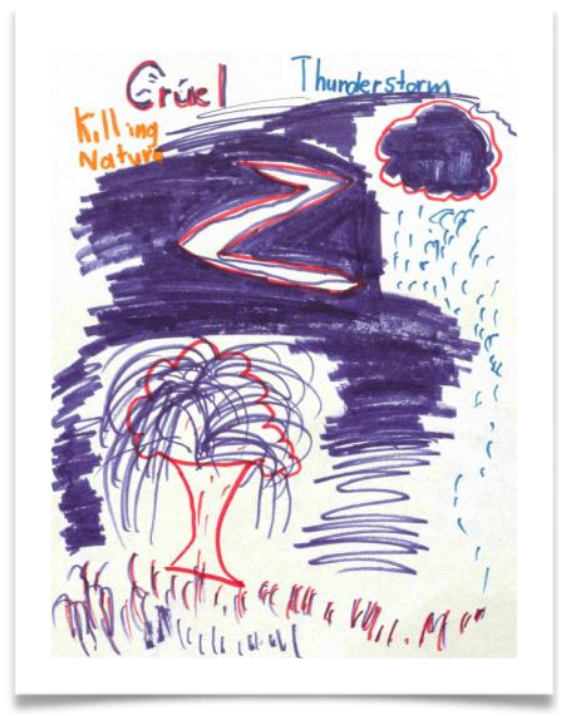

Figure 11. Definition of Nature. This figure is an illustration of how a Canadian girl, Mila, age 9 defined the cruel side of nature

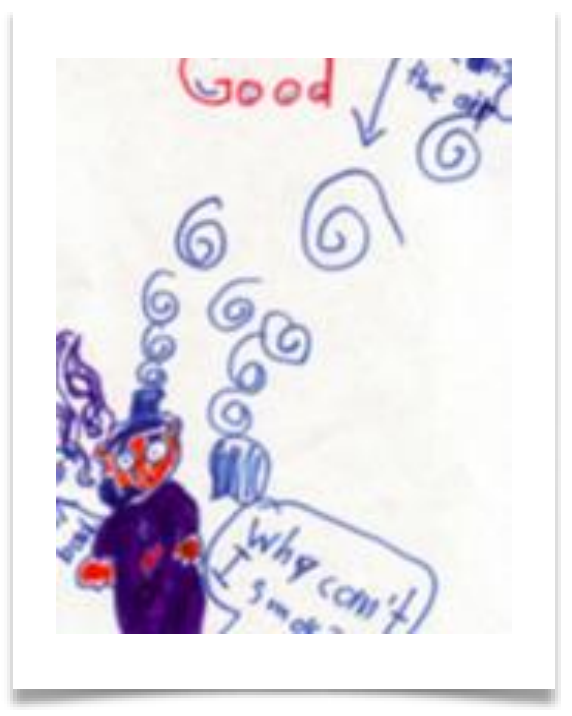

Figure 12. Definition of Nature. This figure is an illustration of how a Canadian boy, Matthew, age 9 defined nature through drawing the air

The younger children do not spend much time with describing or defining nature, but rather simply name the most important functions of nature, i.e. giving food and raw materials to manufacture things or they think about how we ought to live together (like Mila). Mila emphasizes on the unifying aspect of nature: for her humans also belong to nature, because humans are mammals. From there she derives at an ethical obligation that animals do not unnecessarily hurt other animals and because we are animals too, we should not unnecessarily hurt other animals. Mila sees the natural disasters as the cruel side of nature. Similar to the younger German children she points to the moral dimensions of nature.

For Matthew a significant part of nature is air. The achievement of the sevenyear-old boy is that he recognizes the importance of something that cannot be seen with our bare eyes. He criticizes in a concise way the natura naturata (Thomas Aquinus): the from humans created nature is the destruction of natura naturans (Schiemann, 1996). In his painting he contrasts the pure and clean air, that nature gives us, with the polluted air, that is produced by humans. 
nature gives and nature takes: a qualitative comparison between canadian and german children about their concepts of 'nature'

\section{b. the older group of children:}

1 CB Ben (12):

"Nature is a lot of wood... I like beavers. I also think of a certain place that I know in nature, with animals that rustle in the bushes ..."

2 CB Liam (13):

"Nature, is like, a whole bunch of planets in the universe. Without the planets there would be no universe, so without nature there would be no earth."

3 CB James (11):

"Hmm I would say it is everything around you, it's the rocks and the trees and the animal and everything that is around you, right?"

6 CG Simone (13):

"When I think of nature, I think of the beauties of nature ... I think of green, many colours, nothing processed. As part of a large network with many connections."

7 CG Kaitlyn (13):

"When I think of nature I get 2 different images, the first image that comes to mind is animals, and peace and just um like my grand-parent's house because they live in Hope and they have like 24 acres of land and so they've got the mountain. And, my second image is, um...about humans and how they're trashing it, and how we pollute the place and how we're always throwing our garbage and littering."

11 CB Don (12):

"When I think of nature, I think about life, and 'cause trees create oxygen, and without oxygen we wouldn't have life. And also I think nature just creates a balance with the entire world, 'cause nature is part of our world and without it, none of us would be alive, so yeah."

12 CB Liam (13):

“...because you know, we have similarities. Like monkeys are kind of similar with us, and whales are kind of similar with us too. So it's very hard to decide if we are nature or not."

18 CG Simone (13):

Culture is our nature. It's what we believe in. how like mother nature, believes in nature; Our nature is to believe in whatever we believe our culture. And, but-we are kind of mother nature's nature though, be- 
cause we- our - cause- we're from whatever creature we're from that was on this earth before, or maybe still is, and we-if mother nature were to control that animal, the animal-she would've controlled that animal to turn into that human, meaning we were sent from mother nature to keep mother nature alive, not to corrupt it."

The Canadian children begin with the obvious as well: the wood, the beaver, the beloved space (1, CB, Ben, Age 12), everything that is around you" ( $3, \mathrm{CB}$, James, Age 11). Then they become more abstract as is evident through mentioning 'lots of colours, nothing processed' (6, CG, Simone, Age 13). Thus, they all start with a materialistic concept of nature. Simone focusses on the underlying argument that nature is everything that is not made by humans, yet emphasizes on the 'living' when she states: "And basically anything that's alive is part of nature. Because all the buildings and the things that we're doing and building and putting in instead of nature, aren't alive. Whereas the trees, and the bushes and all the moss on the ground- they're alive. And they're sort of what was there before we put them down" (26, CG, Simone, Age 13). By contrast, Liam widens this notion to everything that is in the universe: "Nature, is like, a whole bunch of planets in the universe" (2, CB, Liam, Age 13). He unties himself from the context-specific perspective and widens his definition.

Just like the German children, the Canadian children think that humans are also part of nature. They justify this with pointing towards the origin of humans.. Although Liam refers back to a naturalistic concept of nature, his argumentation is different from the ideas of Luisa. Luisa reasoned that humans cannot make themselves and therefore belong to nature - this is very different from Liam's argument (99, GG, Luisa, Age 9).

In contrast to the German children, the Canadian children included aesthetic aspects in their argumentations when they tried to define nature. For example, Simone says: "When I think of nature I think of natural beauties, so I think of trees and waterfalls" (6, CG, Simone, Age 13), or Kaitlyn expressed, “...the first image that comes to mind is animals, and peace and just like my grandparent's house..." (7, CG, Kaitlyn, Age 13). With those aesthetic qualities like 'beauty', 'harmony' or 'peaceful atmos- 
nature gives and nature takes: a qualitative comparison between canadian and german children about their concepts of 'nature'

phere' the construct of nature receives a corresponding dimension, because the evaluation of 'beauty' has been assigned by the recipient as the interpretation of what is being radiated by the Other. In other words, nature provokes us to make aesthetic judgments. The 'dependency' argument is mainly given by Don in his statement, "When I think of nature, I think about life, and 'cause trees create oxygen, and without oxygen we wouldn't have life" (11, CB, Don, Age 12).

Simone goes beyond the materialistic concept of nature by referring to the 'inner nature' or 'essence' of a person or a thing. Her argument is that it is a part of our nature to create culture. With this argument she is overcoming the dichotomy between nature and culture. Yet her interpretation is not a materialistic interpretation similar to the German children, who argued that furniture is 'made of' natural products; rather Simone is rooting culture in the 'suchness' of human beings. She expands this idea further in her remark that, "our nature is to believe in whatever we believe our culture believes in" (18, CG, Simone, Age 13). She characterizes the nature of human beings to not only 'creating of culture,' but furthermore as one that becomes spiritually, emotionally and socially dependent on its own creation. For her, humans are not only trapped negatively into their own creations, e.g. by destroying nature through culture. For Simone, part of the equipment that we receive from 'mother nature' is also the moral aspiration as well as the task to preserve nature. This is evident when she says, "We were sent from Mother Nature to keep Mother Nature alive, not to corrupt it" (18, CG, Simone, Age 13). In this statement Simone defines nature as a higher order spiritual power as we were sent from Mother Nature as well as a kind of 'being.' The first idea is similar to Goethe's vision of the 'wise Mother Nature'16 while the second definition comes closer to the formal concept of nature by Höffe (2008, p. 223) as "the epitome of all properties of a thing that we can experience as regular or that follow a particular pattern".

${ }^{16}$ Goethe, J. W., “Die Natur" (aphoristisch), um das Jahr 1780. 
Therefore, the additional definitions of nature by the Canadian children are:

- Nature is the entire universe (materialistic extension of the concept of nature)

- Nature is the organization of all living things living together (balanceargument)

- Nature as the provider of good (Mother nature as caring)

- Nature as the provoker of aesthetic judgements (correspondence argument)

- Nature as a higher order creative and spiritual force (Mother nature argument)

- The inherent part of the nature of humans is to create culture (formal concept of nature)

- Humans are part of nature because they descended from the apes (Darwin argument; materialistic concept of nature)

\section{5. implications and conclusion}

Due to the unusual pace of transformation undergoing within contemporary society, the ecological crisis continues to deepen. Therefore, the emotions and conceptualization of nature by children should not be ignored, since they are the ones being mostly affected by those changes. Yet, only if environmental education is in tune with how children relate to nature, children will be encouraged to think and reflect further. This study also highlights how a philosophical approach to teaching and learning can be implemented so to further deepen children's awareness about environment and nature.

This study illustrated that specific relationships can shape our individuality as well as affect our wider human and ecological relationships. The Canadian anthropologist, Wade Davis, explained that the metaphor each individual holds towards nature defines the relationship between that person and the natural world and plays itself differently throughout development. He described that a child from the Andes who believes the mountain to hold the power to direct his or her destiny will grow up to be a different human being than another child in Montana who sees a mountain as a pile 
nature gives and nature takes: a qualitative comparison between canadian and german children about their concepts of 'nature'

of rocks to be mined (Davis, 2007). Such variety in perception of the same phenomena amongst individuals illustrates the fluidity of perception that is heavily influenced by culture. Without knowledge of children's perception and incorporation of their voice into the curricula, it is not clear whose version of nature this future generation will be receiving in education. Given the limitations of a pilot study, this paper addressed the 'definitions' the children gave about 'nature'. We plan to include more participants in this study in order to further explore the other three categories in-depth. Such an investigation will allow for a deeper analysis of aspects that may shape children's views on nature with regards to cultural values, upbringing, and experiences in nature, for example. This pilot study is just the beginning of the learning of different perceptions children have about nature and urges for more research to be done on this topic.

In our pilot study, the main difference between the German and the Canadian children was that the Canadian children tended to personify nature much more, while the Germany students had a tendency to 'objectify' nature. However, we acknowledge the fact that "nature" is an incredibly broad and complex concept. Thus, we are aware that we only tapped into some aspects of this vast phenomenon; especially since the limited inquiry sessions from each country provided only a small sample size. In the future, we would like to increase the sample size, refine our methodology and also include children from other countries.

In addition, we argue for more comparative studies about how children embody nature over and through time, place and space. Further research into how the conception of nature is socially constructed dependent on the availability of resources such as playgrounds and exposure to specific locations would serve an important contribution into the related study of how time and place influence children's conceptions and values of nature. 


\section{6. appendix}

\section{discussion plan}

\section{a. silent impulse}

Photo 1: Teenagers look into a crevice that opened up before them.

Photo 2: There is an apple tree on a meadow and a bench underneath it.

\section{b. free associations and definitions}

1) What is the first thing that comes to your mind, when you think of "nature"?

2) What do you associate with the term 'nature'? How would you define 'nature'?

3) Can one smell, taste, hear, see nature? If so, how? What comes to your mind?

\section{c. nature as dangerous}

4) Have you ever heard of the expression: "force of nature" - Does that expression mean anything to you?

5) Have you ever experienced nature as a "force"?

6) Are there situations where nature can be dangerous? Can you think of some examples? (Have you ever been afraid of nature? If so, when and how?) One sometimes says that nature is "cruel" - What could that mean? Do you agree? Why?

7) Joint-Question: Are there aspects about nature that fascinate you?

\section{d. mother nature or nature as 'giving'}

8) What do you imagine when people use the expression "Mother Nature?"

9) Do you think that humans could survive "without" nature? What would that mean, i.e. to survive "without" nature?

10) Where in your everyday life do you encounter nature? Which situations come to your mind?

11) How do you think/feel about yourself in relation to nature? Do you understand yourself as a part of nature or do you see yourself as something "other" than nature? Explain why?

12) Are there moments where you enjoy and/or admire nature? Or when you even feel awe? If so, can you think of an example?

\section{e. working with concepts and ethical questions}

13) One often says that "nature gives and nature takes". Is that fair?

14) To whom does nature belong? Should nature have "rights", just like human's have "rights"? Do humans have the right to "use" nature for their own survival? 
nature gives and nature takes: a qualitative comparison between canadian and german children about their concepts of 'nature'

15) Imagine you were going to another planet and would have to explain what "nature" is. What would you say?

16) What do you think could be the opposite of nature?

\section{f. meta-discussion}

17) Do you think now differently about nature after our discussion? Which ideas were new to you? If so why? What ideas do you disagree with or seem strange? Why?

18) Is there anything that we have not yet talked about? Something that is still on your mind?

\section{references}

Aristotle., \& Charlton, W. (1992). Aristotle Physics : Books I and II. New York: Oxford University Press.

Berger, R., \& McLeod, J. (2006). Incorporating nature into therapy: A framework for practice. Journal of Systemic Therapies, 25(2), 80-94. Doi: 10.1521/jsyt.2006.25.2.80

Collado, S., Íñiguez-Rueda, L., \& Corraliza, J. A. (2016). Experiencing nature and children's conceptualizations of the natural world. Children's Geographies, 14(6), 716-730. Doi: 10.1080/14733285.2016.1190812

Davis, W. (2007, January). Dreams from endangered cultures [Video file]. Retrieved from <https://www.ted.com/talks/wade_davis_on_endangered_cultures>

Dewey, J. (1927). The public and its problems. New York, NY: Holt and Company.

Eccles, J. S., \& Roeser, R. W. (2009). Schools, academic motivation, and stage-environment fit. Handbook of adolescent psychology. Doi: 10.1002/9780470479193.adlpsy001013

Francis, M., Paige, K., \& Lloyd, D. (2013). Middle years students' experiences in nature: A case study on nature-play. Teaching Science, 59(2), 20-30.

Goethe, J.W., Reimer, F. W., \& Eckermann, P. (1837). Goethe's poetische und prosaische Werke in zwei Bänden: in zwei Bänden. Germany, Cotta.

Gurholt, K. P., \& Sanderud, J. R. (2016). Curious play: children's exploration of nature. Journal of Adventure Education and Outdoor Learning, 16(4), 318-329.

Höffe, O. (2008). Lexikon der Ethik. 7. neubearbeitete und erweiterte Auflage. München: Verlag C.H. Beck.

Kennedy, D. (2004). The role of a facilitator in a community of philosophical inquiry. Metaphilosophy, 35(5), 744-765. Doi: 10.1111/j.1467-9973.2004.00348.x

Marsal, E., \& Dobashi, T. (2009). Empirical evaluation of philosophy instruction (P4C): Models, methods, examples in children philosophize worldwide. In E. Marsal, T. Dobashi, \& B. Weber (Eds.), International theoretical and practical concepts (pp. 473-478). Frankfurt: Peter-Lang-Verlag. Maykut, P., Morehouse, R. (1994). Beginning qualitative research: A philosophical and practical guide. Los Angeles, CA: Routledge Falmer.

Mayring, P. (2007). Qualitative Inhaltsanalyse: Grundlagen und Techniken (9th ed.). Frankfurt, Germany: Beltz Pädagogik.

Meyer-Abich, K.: (1989) Eigenwert der natürlichen Mitwelt und Rechtsgemeinschaft der Natur, in: Altner, G. (Hg.): Ökologische Theologie, Stuttgart, 254-276. 
Meyer-Abich, K.-M. (1997) Praktische Naturphilosophie. Erinnerung an einen vergessenen Traum, München.

Pätzold, Hartmut: Naturphilosophie. [online] URL: http://www.philosophiewoerterbuch.de/online-

woerterbuch/?tx_gbwbphilosophie_main[entry]=591\&tx_gbwbphilosophie_

main[action]=show\&tx_gbwbphilosophie_main[controller]=Lexicon\&cHash=fc341ca540a1002 47ec01704be37c527 [Stand: 22.02.2013]

Schäfer, Lothar. (1998). Natur. In: Korff, Wilhelm / Beck, Lutwin / Mikat, Paul: Lexikon der Bioethik. Band 2. Gütersloh: Gütersloher Verlagshaus, S. 728-733.

Schiemann, G (Hrsg.). (1996). Was ist Natur? Klassische texte zur Naturphilosophie. München: Deutscher Taschenbuch Verlag.

Spaemann, Robert. (1973): Natur. In: Krings, Hermann / Baumgartner, Hans Michael / Wild, Christoph (Hrsg.): Handbuch Philosophischer Grundbegriffe. Band 2. München: Kösel-Verlag, S. 956-969.

Weber, B. (2013). Philosophieren mit Kindern zum Thema Menschenrechte: Vernunft und

Mitgefühl als Grundvoraussetzungen einer demokratischen Dialogkultur. Freiburg,

Germany: Alber Publisher

White, E. J. (2015). Seeing is Believing? Insights from young children in nature. International Journal of Early Childhood, 47, 171-188. Doi: 10.1007/s13158-014-0118-5

Zhang, W., Goodale, E., \& Chen, J. (2014). How contact with nature affects children's biophilia, biophobia and conservation attitude in China. Biological Conservation, 177, 109-116. https://doi.org/10.1016/j.biocon.2014.06.011.

received in: 17.08 .2017

approved in: 02.02.2018 